\title{
Uzaktan Eğitim Sürecinin Değerlendirilmesi: Fen Bilimleri Öğretmenlerinin Görüşleri
}

\author{
Özlem YUNUS ${ }^{1} \quad$ Zehra YILDIRIM ${ }^{2} \quad$ Serpil KALAYCI ${ }^{3}$
}

Gönderim Tarihi: 19.04.2021

Kabul Tarihi: 26.09 .2021

Yayın Tarihi: 19.10 .2021

\begin{abstract}
Öz: 2020 yılının sonlarına doğru Çin'de ortaya çıkan ve tüm dünyayı etkisi altına alan Covid-19 salgını eğitim öğretim faaliyetlerini de etkilemiş, buna bağlı olarak tüm ülkede uzaktan eğitime geçilmiştir. Hızlı ve ani bir şekilde değişen eğitim öğretim anlayışı sonucunda salgının etkilerinin araştırıldı̆̆ı uzaktan eğitime yönelik araştırmalar daha da önem kazanmıştır. Bu bağlamda gerçekleştirilen bu araştırmanın amacı, fen bilimleri öğretmenlerinin uzaktan eğitime yönelik görüşlerini ortaya koymaktır. Uzaktan eğitimin öğretmen ve öğrenci üzerindeki etkileri, fen bilimleri öğretmenlerinin yaşadıkları sorunlar ve sürece dair görüşlerinin ortaya çıkarılması hedeflenmiştir. Araştırmada nitel araştırma yöntemlerinden olgu bilim kullanılmıştır. Araştırmanın araştırma grubunu eğitim öğretim faaliyetlerini uzaktan gerçekleştiren 10 fen bilimleri öğretmeni oluşturmuştur. Veriler, araştırmacıların hazırlanmış olduğu yarı yapılandırılmış görüşme formu aracılığıyla toplanmıştır. Verilerin analizinde içerik analiz tekniği kullanılmıştır. Araştırma bulguları; uzaktan eğitim sürecinde fen bilimleri öğretmenlerinin kullandığı yöntemleri, uzaktan eğitim sürecinin avantajları, dezavantajları, karşılaştıkları sorunları çözme yöntemlerini içermektedir. Buna göre, fen bilimleri öğretmenlerinin uzaktan eğitime dair, eğitimde öğretme-öğrenme süreci, iletişim-etkileşim ve ölçme-değerlendirme açısından olumsuz yönelik görüşlere sahip oldukları görülmüştür.
\end{abstract}

Anahtar Kelimeler: Uzaktan eğitim, Fen bilimleri öğretmeni, görüş, Covid-19

\section{Evaluation of Distance Education Process: The Opinion of Science Teachers}

\begin{abstract}
The Covid-19 epidemic, which emerged in China towards the end of 2020 and affected the whole world, also affected education activities, and accordingly, distance education was started all over the country. As a result of the rapidly and suddenly changing education and training approach, research on distance education, in which the effects of the epidemic are investigated, has gained even more importance. The aim of this study, which was carried out in this context, is to reveal the views of science teachers about distance education. It is aimed to reveal the effects of distance education on teachers and students, the problems experienced by science teachers and their views on the process. Phenomenology, one of the qualitative research methods, was used in the study. The research group of the study consisted of 10 science teachers who carried out educational activities remotely. The data were collected through a semi-structured interview form prepared by the researchers. Content analysis technique was used in the analysis of the data. Research findings; It includes the methods used by science teachers in the distance education process, the advantages and disadvantages of the distance education process, and the methods of solving the problems they encounter. Accordingly, it was observed that science teachers had negative views on distance education in terms of teaching-learning process in education, communicationinteraction and measurement-evaluation.
\end{abstract}

Keywords: Distancelearning, opinion, Scienceteacher, Covid-19

\section{GİRİŞ}

21.yüzyılda eğitim ve öğretimi en çok etkileyen kavramlar; teknoloji ve teknolojide yaşanan gelişmelerdir. Teknolojideki değişimler ve gelişmeler dünyayı her alanda etkilediği gibi, eğitimöğretimi de etkilemiş, eğitimde birtakım değişimlere ve dönüşümlere neden olmuştur. Eğitimöğretimi etkileyen en önemli değişimlerden birisi de uzaktan eğitimdir. Eğitime entegre edilen uzaktan eğitim teknolojideki gelişmelerle zenginleşmiştir (Koloğlu,2016). Bu zenginleşmeler öğrenen için bilgiye ulaşmada yeni yol ve yöntemler anlamına gelmektedir.

Uzaktan eğitime yönelik ilk faaliyet, 1840 yılında İngiltere' de öğretimde mektupların kullanılması

\footnotetext{
${ }^{1}$ Mersin Üniversitesi, Türkiye, ozlemyunus07@gmail.com , ORCID: 0000-0002-7228-3105

${ }^{2}$ Mersin Üniversitesi, Türkiye, zehra.fizik.1987@hotmail.com, ORCID: 0000-0003-2217-1639

${ }^{3}$ Hatay Mustafa Kemal Üniversitesi, Türkiye, serpilkalayci36@hotmail.com, ORCID: 0000-0001-9613-3390
} 
ile başlamışır (Moore ve Kearsley, 1996). Gelişmiş ülkeler başta olmak üzere birçok ülke uzaktan eğitimi fark etmiş ve bu konuya yönelik çeşitli girişimlerde bulunmuşlardır. Daha sonra teknolojinin gelişmesine bağlı olarak özellikle 20.yüzyıldan itibaren kitle iletişim araçlarındaki değişim ve gelişmeler, uzaktan eğitime de farklı bir boyut kazandırmıştır. Radyo, televizyon, bilgisayar gibi araçların keşfedilmesiyle bu gelişmeler uzaktan eğitim içerisinde yerini almaya başlamıştır (Kırık, 2014). Türkiye' de ise ilk kez 1927 yılında başlayan bu uzaktan eğitim süreci ilk olarak okuma yazma faaliyetlerinin arttırılması kapsamında mektuplar aracılığıyla öğretime entegre edilmeye çalışılmış, fakat aktif uygulamaya geçilememiştir (Alkan, 1987). Başta düşüncede kalan uzaktan eğitim faaliyetleri ilk kez Türkiye' de 1956 yılında Ankara Üniversitesin 'de gerçekleştirilmiştir (Zırhlıŏ̆lu, 2006). Mektupla başlaya uzaktan eğitim süreci daha sonra radyo, televizyon, video ve bilgisayarın gelişmesiyle eğitim ve öğretimde destek amaçlı kullanılmaya devam etmiştir (Höçük, 2011, Tuncer ve Tanaş, 2011). Uzaktan eğitim uygulamaları zaman içerisinde artmış ve son yıllarda gelinen noktada üniversiteler bünyesinde uzaktan eğitim merkezleri kurulmuştur. Hatta birçok üniversitenin zorunlu ortak dersleri (Türk dili, inkılap tarihi ve İngilizce vb.) uzaktan eğitim yoluyla verdikleri görülmektedir (Özbay, 2015).Tarihsel yolculuğu bu şekilde başlayan uzaktan eğitim kavramı; öğrenen ile öğretenin aynı zaman ve mekânda olma gibi zorunluluklara bağlı kalmadan ve aralarındaki etkileşimin teknolojideki gelişimlerle elde edilen elektronik iletişim araçlarıyla sağlandığı eğitim-öğretim şekli olarak da tanımlanabilir. Bu elektronik iletişim araçları; mektup, radyo, televizyon, uydu, bilgisayar ve internet olarak siralanabilir (United StatesDistance Learning Association (USDLA), 2004). Buna bağlı olarak uzaktan eğitim-öğretim; e-öğrenmeyi, mesajlaşmayı, sosyal ağları, sanal dünyayı, web seminerlerini akla getirmektedir (Moore ve Kearsley, 2011). Bütün bu araçlar, bir araya gelerek harmanlamış bir mobil öğrenmeyi ön plana çıkarmaktadır.

Uzaktan eğitim her ne kadar zaman ve mekândan bağımsız olarak görünse de, yüz yüze eğitimle karşılaştırıldığında öğretmen ve öğrencilerin rollerinde birtakım farklılıklar olduğu görülmektedir. Yüz yüze eğitimde öğretmenlerin görevleri; öğrenciyi tanıma, eğitim-öğretimi planlama-yapmayönetme, araç-gereç tasarlama, öğrenciye rehberlik etme ve onların gelişime açık olmaları için çaba harcama şeklinde siralanabilirken, uzaktan eğitimde ise belirtilen bu görevlerin yanı sira öğretmenin gerektiğinde teknoloji uzmanı, site eğitmeni, araştırmacı roller de üstlenmesi gerekmektedir (Karadağ ve Şen, 2014). Aynı zamanda öğretmenlerin esnek ve öğrenen koşullarına uygun hareket etmesi de bu beklentilerden biridir.

Uzaktan eğitim diğer eğitim-öğretim yöntemlerinde olduğu gibi bünyesinde avantajlar ve dezavantajlar barındırmaktadır. Öğrenene; zaman ve mekândan bağımsız öğrenme fırsatı verme, öğrenenler arasındaki fırsat eşitsizliğini giderebilme ve öğrenene bireysel sorumluluk kazandırma fırsatı sağlaması uzaktan eğitimin en önemli avantajlarındandır. Ayrıca uzaktan eğitim sayesinde, farklı nedenlerle öğretim hayatından uzaklaşan bireyler öğrenimlerine hayat boyu devam edebilme fırsatı bulabilmektedir. Yine uzaktan eğitim birçok farklı disiplin için esnek uygulama olanağı sağlayabilmektedir (Uşun, 2006). Aktay'a (2002)'ye göre ise uzaktan eğitim küreselleşmeye katkı sağlayarak öğrenmeyi okuldan bağımsız hale getirmektedir. Böylece bireyler internet aracılığıla okulun baskıcı tutumu olmaksızın daha verimli öğrenebilmektedir. Birkök (1998) ise uzaktan eğitimin dezavantajlarına dikkat çekmiş, yüz yüze iletişimden farklı olarak oluşturulan sanal grupların, etkileşimin sınırlılığı nedeniyle düşük performans gösterdiklerini savunmuştur.

Uzaktan eğitim sonucu öğrencilerin sosyal yaşamdan uzaklaşması uzaktan eğitimin en büyük dezavantajı olarak söylenebilir. Bilişsel becerilerin kullanıldığı dersler uzaktan eğitime kolayca entegre edilebilirken duyusal ve devinimsel becerilerin kazandırılmasında uzaktan eğitimin yetersiz kalması diğer dezavantajlarından biridir (Tabata ve Johnsrud, 2008). Uzaktan eğitim 
teknolojik gelişmelere paralel olan bir öğretim şekli olduğundan eğitim uygulayıcılarının bu alanda donanımlı olması ve öğrencilerin motivasyonlarını sağlanmasında gereken bilgi ve beceriye sahip olması dolayısıyla uygulayıcı açısından daha fazla çaba harcanması gerekliliği uzaktan eğitimin başka bir dezavantajı olarak gösterilebilir. Ayrıca uzaktan eğitim sürecinde öğrencilerin iletişim teknolojilerine bağımlılık geliştirmesi olasılığı da bir dezavantaj olarak sunulabilir (Ağır, 2005; Lloyd, Byrne ve McCoy, 2012). Yüz yüze eğitimde olduğu gibi uzaktan eğitim sürecinde de öğrenci kendi başarısından sorumludur. Bu bağlamda öğrenenin uzaktan eğitimde başarılı olması için teknolojik gelişmelere uyum sağlamalı, derslere katılım göstermeli, eş zamanlı ve ayrı gerçekleştirilen uzaktan eğitim etkinliklerine gereken katılım göstermelidir (Simonsonvd, 2012). Uzaktan eğitim sürecinde öğrencilerin öğrenme kaynaklarının azalmasından dolayı öğrenenlerin tek başına bu sürecin sorumluluğunu daha fazla alması gerekmektedir.

Uzaktan eğitim; tarihi, tanımı, avantajları ve dezavantajlarıyla yukarıda anlatıldı̆̆ı şekilde rutin bir akışta eğitim-öğretim dünyasında kendine bir yer bulmaya çalışırken, 22 Mart tarihinde Türkiye'de ve diğer dünya ülkelerinde hızla yayılan COVID-19 salgını nedeniyle okullarda yüz yüze eğitime ara verilmesi kararı onu birden tek seçenek haline getirmiştir. Salgın döneminde uzaktan eğitim faaliyetleri; televizyon kanalları, video kayıtları ve çeşitli ödevlerle gerçekleştirilmeye çalışılmıştır. Salgın nedeniyle yüz yüze eğitime ara verilmesine bağlı olarak uzaktan eğitimin uygulanışı, algılanışı ve tutumlarına yönelik araştırmalar daha da önem kazanmıştır. Bu süreçte öğretmenlerin ve öğrencilerin beklentilerinin ne olduğu oldukça önemlidir (Marsh vd., 2010).

$\mathrm{Bu}$ araştırmanın amacı, Fen bilimleri öğretmenlerinin uzaktan eğitim sürecine ilişkin görüşlerini belirlemektir. Milli Eğitim Bakanı yaptığı son açıklamalarda pandemi süreci son bulsa dahi eğitimin \%20'sinin bundan sonraki süreçte sabit bir şekilde uzaktan gerçekleşeceğini yani uzaktan eğitimin, eğitim sisteminde kalıcı olacağını vurgulamıştır (Selçuk, 2021). Dolayısıyla uzaktan eğitim sürecinin önemli kollarından olan öğretmenlerin ne tür sorunlar yaşadıkları ve derslerin işlenmesi sırasında karşılaştıkları sorunların çözümüne yönelik görüşleri bugün ve gelecek adına önem taşımaktadır. $\mathrm{Bu}$ araştırma kapsamında, fen bilimleri öğretmenlerinin uzaktan eğitimin avantajları/dezavantajları hakkındaki görüşlerini, bu süreçte karşılaştıkları sorunları çözme yöntemlerini ve uzaktan eğitimin etkililiğini artırmaya yönelik önerilerini ortaya koymak amaçlanmaktadır. COVID-19 salgınının gündemi işgal eden ve etkisi hâlâ devam eden bir durum olması, araştırmanın güncel yönünü yansıtmaktadır. Bu noktadan hareketle araştırmanın alan yazına katkı sunacağı öngörülmektedir.

\section{YÖNTEM}

$\mathrm{Bu}$ araştırma Mustafa Kemal Üniversitesi Sosyal ve Beşeri Bilimler Etik Kurulu tarafından 07/02/2021 tarihli ve E-21817443-050.99-11524 sayılı karar ile onaylanmıştır.

Araştırma kapsamında, uzmanlar tarafından önceden hazırlanmış yarı yapılandırılmış görüşme soruları işe koşulmuştur. Bu araştırmada, yapılan görüşmelerden elde edilen verilerin derinlemesine analizinin yapılması amacıyla nitel araştırma yaklaşımlarından biri olan olgu bilim (Fenomenoloji) kullanılmıştır. Farkında olunan fakat derinlemesine ve detaylı bir anlayışa sahip olmadığımız olgulara odaklanılması olgu bilim (fenomenoloji) deseni olarak adlandırılmaktadır (Yıldırım ve Şimşek, 2008). Nitel araştırmalarda insanın doğasına ilişkin algı ve olayların, doğal yaşam ortamında ve sosyal gerçeklikte olabildiğince detaylı incelenmesi söz konusudur (Morgan, 1996). Nitel araştırmalar, kendi çerçevesinde incelenen durum veya olayı yorumlayıcı ve keşfedici bir yaklaşımla ele alır (Malterud, 2011). Böylece farklı araştırma alanlarındaki disiplinleri bir araya getiren bütüncül bir yaklaşımın ortaya konulduğu söylenebilir (Hatch, 2002). Bu yaklaşımda elde 
edilen veriler öznel ve kişisel görüşlere dayanmaktadır (Shenton, 2004).

\section{Araştırma Modeli}

Araştırmada fenomenoloji kullanılmıştır. Olgu bilim olarak da adlandırılan fenomenolojinin cevap aradığ1 soru "Gerçek nedir?" sorusudur. Bu yaklaşımının temelinde bireysel tecrübeler yer almaktadır. Fenomenoloji yaklaşımda araştırmacı, katılımcının bireysel (öznel) deneyimleri ile ilgilenmekte, bireyin algılamalarını ve olaylara olan bakış açılarını ortaya koymaktadır. Fenomenolojide amaç daha çok tanımlama yapmaktır. Dolayısıyla genelleme yapmaktan ziyade olguları tanımlamak önemlidir (Baş ve Akturan, 2008,). Fen bilimleri öğretmenlerinin görüşlerinden yola çıkarak uzaktan eğitim sürecinde Fen bilimleri öğretmenlerinin yaşadıkları sorunları ayrıntılı bir şekilde ortaya koymak ve katılımcıların belirttikleri çözüm önerilerinden hareketle çıkarımlarda bulunularak derinlemesine inceleme yapmak için olgu bilim deseni tercih edilmiştir.

\section{Katılımcilar}

$\mathrm{Bu}$ araştırmanın araştırma grubu, Hatay'ın farklı ilçelerinde görev yapan 10 fen bilimleri öğretmeninden oluşmaktadır. Bu öğretmen adaylarının 5'i kadın 5'i de erkeköğretmendir. Araştırma grubunda yer alan fen bilimleri öğretmenlerinin isimlerinin belli olmaması için etik kurallar doğrultusunda, öğretmenlere Ö1, Ö2, Ö3, Ö4 şeklinde rumuzlar verilmiştir.

Derinlemesine araştırma yapabilmek amacıyla araştırmanın amacı bağlamında bilgi açısından zengin durumların seçilmesine amaçlı örneklem denir (Büyüköztürk, 2012). Amaçlı örneklemede araştırmacılar ana olgu hakkında bilgi edinmek veya onu anlamak için bireyleri ve araştırma mekânlarını amaçlı bir şekilde seçerler (Creswell, 2017). Araştırma grubu belirlenirken amaçlı örneklem stratejilerden belli kriterlerin sağlandığı, bazı durumların önceden belirlenip katılımcıların ona göre seçildiği, ölçüt örneklem stratejisi kullanılmıştır. Burada yer alan iki ölçüt söz konusundur. Bu ölçütler fen bilimleri öğretmenlerinin araştırmaya gönüllük esasına göre katılmaları ve uzaktan eğitim sürecinde ders veren aktif katılımcılar olmalarıdır.

\section{Veri Toplama Araçları}

$\mathrm{Bu}$ araştırma kapsamında, araştırmacılar tarafından geliştirilen fen bilimleri öğretmenlerinin uzaktan eğitim ile ilgili 10 soruluk görüşlerini inceleme formu kullanılmıştır. Yarı yapılandırılmış görüşme formu soruları araştırmacılar tarafından literatür taraması yapıldıktan sonra, güncel uygulamalar bağlamında değerlendirilerek oluşturulmuştur. Oluşturulan taslak görüşme formu bir öğretim üyesinin ve 2 fen bilimleri öğretmeninin değerlendirmesine sunulmuştur. Başlangıçta oluşturulan form, 14 açık uçlu sorudan oluşmasına rağmen 4 tanesinin diğerleriyle içerik olarak benzeşmesinden ötürü uzmanların çıkarılmasına yönelik önerisi doğrultusunda 10 soruya düşürülmüş ve bazı sorular dil bakımından düzeltilmiştir. Ayrıca araştırmanın katılımcıları dışındaki bir fen bilimleri öğretmeni ile pilot görüşmeler yapılarak görüşme formunun anlaşılırlığı test edilmiştir. Veri toplama süreci, salgından dolayı bu araştırmaya katılan öğretmenler ile telefon görüşmeleri ve internet üzerinden e posta yazışmaları yoluyla gerçekleştirilmiştir. Yine geçerlilik ve güvenirliliği sağlamak amacıyla uzmanlardan da görüş ve öneriler alınmıştır. Yapılan görüşmelerde gönüllülük esas alınmış ve görüşme başlamadan önce araştırma hakkında ön bilgilendirmenin bulunduğu katılımcı onay formu imzalatılmıştır.

Nitel araştırmalarda geçerlik ve güvenirlik çalışmaları nicel araştırmalara göre farklılık göstermektedir. Nitel araştırmalarda geçerlik ve güvenirliğin ölçütü araştırmanın her aşamasında şeffaf olmak, işlemleri ayrıntılarıyla açıklamak ve verileri ayrıntılı olarak raporlamak olarak açıklanabilir. (Yıldırım ve Şimşek, 2008). Bu araştırmada da işlemlerin süreç boyunca ayrıntılı olarak 
açıklanmasına özen gösterilmiştir. Veri toplama araçlarının geliştirilmesi sürecinde de uzman görüşleri alınmıştır. İç güvenirliğin sağlanması noktasında kodlayıcılar arasında işbirliği yapılmış ve ortak görüşler alınarak hesaplanmıştır. Bu hesaplamada Miles ve Huberman (1994)'in nitel araştırmalar için kullanılan güvenirlik katsayısı formülü (güvenirlik = görüş birliği / (görüş birliği + görüş ayrılığı) x100) kullanılmıştır. Miles ve Huberman (1994) geliştirdikleri formülde güvenirliğin sağlanması için minimum değerinin 0.70 olması gerektiğini önermişlerdir. Araştırma sürecinde de toplanan veriler yazılı metinler halinde araştırmacılar tarafından ayrı ayrı kodlanmış, görüş birliği çerçevesinde benzer olan ve farklı kodlanan kodlamalar dikkate alınarak araştırmacılar arasındaki görüş birliği 0.88 .15 olarak hesaplanmıştır. Dış güvenirliğin sağlanması noktasında katılımcıların özellikleri tanımlanmalı, sınırlılıklar açıklanmalıve verilerin toplanma ve analiz edilme sürecinden bahsedilmesi gerekmektedir (Yıldırım ve Şimşek, 2013). Bu doğrultuda bu süreçler araştırma kapsamında ayrı olarak uygun başlıklar altında açıklanmış ve bu şekilde dış güvenirlik sağlanmaya çalışılmıştır. Araştırmada yer alan sorular şunlardır;

1- Fen bilimleri derslerinde kullandığınız uzaktan eğitim araçları nelerdir?

2- Fen bilimleri derslerinde uzaktan eğitim, teknoloji bağımlılı̆̆ını tetikler mi? Neden?

3- Fen bilimleri derslerinde uzaktan eğitime katılan öğrencilerin yaşı ve cinsiyeti önemli midir? Neden?

4- Fen bilimleri derslerinde uzaktan eğitimde hangi yöntem-tekniklerin kullanılması akademik başarıyı ve motivasyonu destekler?

5- Fen bilimleri derslerinde uzaktan eğitimde çevrimiçiuygulamalar etkili midir? Neden?

6- Fen bilimleri derslerinde uzaktan eğitimin verimliliği hakkında ne düşünüyorsunuz?

7- Fen bilimleri derslerinde uzaktan eğitimin kullanılması gelecekte çocukları nasıl etkiler?

8- Fen bilimleri derslerinde gelecekte uzaktan eğitim uygulamaları artar mı? Neden?

9- Fen bilimleri derslerinin uzaktan eğitim ile işlenmesinde karşılaştı̆̆ınız sorunlar nelerdir?

10-Fen Bilimleri Derslerinin uzaktan eğitim ile işlenmesinde öğretmen ve öğrenciler için önerileriniz nelerdir?

\section{Verilerin Analizi}

Nitel veriler öğretmenler ile yapılan görüşmeler sonucunda oluşturulmuştur. Görüşmenin temel amacı; ilgili konuya yönelik ayrıntılı, detaylı ve çok boyutlu nitelikli bilgi elde etmektir (Glesne, 2012). Verilerin analizi yapılırken görüşmelerden elde edilen veriler ile ilgili içerik analizi yapılmıştır. Katılımcılara yöneltilen her sorunun cevabı derinlemesine incelenmiştir. Her cevap tekrar tekrar incelenmiş ve analiz sürecinde tümevarımsal analiz yöntemi benimsenmiştir. Önce kodlama ardından benzer kodların birleştirilmesiyle alt tema oluşturmuş ve son olarak alt temaları bir araya getiren ana temalar oluşturulmuştur. Veriler kodlanırken daha önceden belirlenmiş kavramlar ve verilerden çıkan kavramlar dikkate alınmıştır. Veriler iki araştırmacı tarafından ayrı ayrı kodlanmış ve aralarındaki uyum yüzdesi 88,15 saplanmıştır. Kodlardaki anlaşmazlıkları çözmek için her iki araştırmacı farklılıkları tartışmıştır. Daha sonra veriler tabloları oluşturularak yorumlanmıştır

\section{BULGULAR}

Bu kısımda öğretmenler ile yapılan görüşme sonrasında elde edilen bulgulara yer verilmiştir. Elde edilen bulgular aşağıdaki tablolarda belli bir sıra ve düzen içerisinde sunulmuştur.

Araştırmanın birinci sorusu "Fen Bilimleri Derslerinde kullandığınız uzaktan eğitim araçları 
nelerdir?" şeklinde olup elde edilen tema ve kodlar aşağıda verilmiştir (Tablo 1).

Tablo 1. Birinci Soruya ait Tema ve Kodlar

\begin{tabular}{|c|c|c|}
\hline Tema & Kodlar & Frekans \\
\hline \multirow{19}{*}{ Uzaktan Eğitim Programları } & Zoom & 10 \\
\hline & EBA & 10 \\
\hline & Whatsapp & $\begin{array}{l}6 \\
5\end{array}$ \\
\hline & Online deney siteleri & \\
\hline & Skype & 3 \\
\hline & Microsoft teams & 4 \\
\hline & Whiteboard & 1 \\
\hline & Facetime & 1 \\
\hline & Youtube & 1 \\
\hline & Facebook & 1 \\
\hline & $\begin{array}{l}\text { Facebook } \\
\text { Instagram }\end{array}$ & 1 \\
\hline & & 1 \\
\hline & Google Meet & 1 \\
\hline & Ppt sunumları & 1 \\
\hline & Zümre odaları & 1 \\
\hline & Video & 1 \\
\hline & Z Kitap uygulamaları & 1 \\
\hline & Mikroskop görüntüleri & 1 \\
\hline & Animasyon & 1 \\
\hline \multirow{14}{*}{ Web 2.0 Tasarım Araçları } & Kahoot & 4 \\
\hline & Socrative & 1 \\
\hline & Padlet & 1 \\
\hline & Stellarium & 1 \\
\hline & Powtoon & 1 \\
\hline & Nearorpord & 1 \\
\hline & Wordwall & 2 \\
\hline & Moddle & 1 \\
\hline & Quziz & 2 \\
\hline & Google classrom & 2 \\
\hline & Learning apps & 1 \\
\hline & Canva & 1 \\
\hline & Team link & 1 \\
\hline & & 1 \\
\hline \multirow{6}{*}{ Uzaktan Eğitim Cihazları } & Bilgisayar & 1 \\
\hline & Tablet & 1 \\
\hline & Telefon & 2 \\
\hline & Z kitaplar & 1 \\
\hline & Grafik tablet & 1 \\
\hline & Notebook & 1 \\
\hline
\end{tabular}

Tablo 1 incelendiğinde, öğretmenlerin çoğunun uzaktan eğitimde aynı programı kullandığ 1 görülmektedir. Özellikle Zoom, EBA ve Whatsapp programlarının uzaktan eğitimin tercih edilen uygulamaları olduğu söylenebilir. Yine günümüz eğitim-öğretim müfredatlarında giderek yaygın kullanılmaya başlanılan Web 2.0 tasarım araçları da öğretmenler tarafından dile getirilmiştir. Bu soruyu teknik cihaz olarak cevaplayan öğretmenler de telefon, tablet, bilgisayar gibi elektronik cihazları vurgulamıştır. Araştırmanın ilk sorusuna yönelik bazı öğretmenlerin görüşleri aşağıda verilmiştir: 
“Uzaktan eğitim araçları denilince aklıma bilgisayar, tablet ve telefonlarda kullandığım Zoom, EBA, Skype ve WhatsApp uygulamaları gelmektedir. Fen bilimleri derslerinde yoğun olarak Web 2.0 araçlarını da kullanıyorum. Örnek vermek gerekirse Kahoot, Padlet ve Socrative verilebilir. Astronomi konularında Stellarium ve yine video hazırlarken Powtoon kullandı̆̆ım diğer Web 2.0 araçlarıdır".(Ö2)

"Uzaktan eğitimde ders anlatırken Zoom, EBA, Facebook, Instagram gibi uygulamaları kullanıyorum. Konu anlatımı özellikte internetten z kitap uygulamalarını araştırıyorum. Fen bilgisi öğretmenlerinin olduğu zümre odalarında da bazen işime yarayacak ders materyalleri bulabiliyorum. Derslerde video, powerpoint sunumlarını sıkça kullanıyorum. Özellikle mikroskop görüntüleri öğrencilerin dikkatini oldukça çekiyor". (Ö7)

Araştırmanın ikinci sorusu “Fen Bilimleri Derslerinde uzaktan eğitim, teknoloji bağımlılı̆̆ını tetikler mi? Neden?" şeklinde olup elde edilen tema ve kodlar aşağıda sunulmuştur (Tablo 2).

Tablo 2. İkinci Soruya ait Tema ve Kodlar

\begin{tabular}{lll}
\hline Tema & Kod & Frekans \\
\hline & Dikkat dağıtmak & 1 \\
& Dijital dünya & 1 \\
& Bilgisayar & 1 \\
Bağımlilık nedenleri & Zaman geçirme & 6 \\
& Oyun & 3 \\
& Film & 1 \\
& Dizi & 1 \\
& Firsat & 3 \\
& Ailenin ihmali & 2 \\
\hline
\end{tabular}

Araştırmanın ikinci sorusuna ilişkin öğretmenlerin görüşleri incelendiğinde, bu araştırmaya katılan öğretmenlerin \%80'i uzaktan eğitimin teknolojik bağımlılığı tetiklediğini, geriye kalan öğretmenlerin \% 20'si ise uzaktan eğitimin, teknolojik bağımlılığı etkilemediğini düşünmektedir. Öğretmenler bu süreçte, öğrencilerin teknolojik araçlarla daha çok zaman geçirdikleri için teknoloji bağımlılığının arttığını belirttirmiştir. Yine öğrencilerin uzaktan eğitim nedeniyle elektronik cihazlar zaman geçirmek için fırsat buldukları ve bu fırsatı oyun oynama, film ve dizi izleme olarak değerlendirdikleri için bağımlılığın arttığını belirtilen öğretmen görüşleri de mevcuttur. İkinci soruya yönelik bazı öğretmenlerin görüşleri aşağıda verilmiştir:

“Öğrencilerin dikkatini dağıtacak binlerce unsurun bulunduğu günümüzde bu unsurların en etkililerinden biri de dijital dünyadır. Öğrenci bilgisayar karşısında olması gerekenden fazla zaman geçirdiğinde, bazı durumlarda öğrencinin derse olan ilgisi azalmakta ve oyun, film, dizi vs. yönelebilmektedir. Bu da uzun vadede teknoloji bağımlılı̆̆ına sebebiyet verebilir".(Ö1)

"Ebeveynler yasaklarla çocuklarını teknolojik araç ve gereçlerden uzak tutmaya çalışırken, farkında olmadan çocuklarda heves oluşturuyorlar. Ve uzaktan eğitim ile artık bütün bu teknolojik araç gereçler çocuklarm ellerinde olduğundan, öğrenciler de firsat buldukça oyun oynamaya çalışıyorlar. Bu durum da çocuklarda bağımlılı̆̆a sebep olabiliyor. Erkek öğrencilerde bu oranın daha yüksek olduğunu düşünüyorum". (Ö3)

"Fen bilimleri dersinin uzaktan eğitimde teknolojik bağımlılı̆̆ı tetikleyeceğini düşünmüyorum. Aksine araştırmacı yönlerini daha çok tetiklediğine inanıyorum. Öğrenciler bir konu hakkında araştırmalar yaparken bana aynı konu ile bağlantılı daha farklı ve güncel konulardan bahsedebiliyor. Öğrencilerde teknoloji bă̆ımlılı̆̆ı daha çok ailelerin tutumuyla 
ilişkilidir. Öğrenciler teknolojiyi amacına uygun kullandıkları sürece, uzaktan eğitimde dersimizin bă̆ımlılıkla bir ilişkisinin olmayacağını düşünüyorum". (Ö10)

Araştırmanın üçüncü sorusu “Fen Bilimleri Derslerinde uzaktan eğitime katılan öğrencilerin yaşı ve cinsiyeti önemli midir? Neden?" şeklinde olup elde edilen tema ve kodlar aşağıda verilmiştir (Tablo $3)$.

Tablo 3. Üçüncü Soruya ait Tema ve Kodlar

\begin{tabular}{lll}
\hline Tema & Kod & Frekans \\
\hline Yaş & Ders planı & 1 \\
& Teknoloji kullanımı & 1 \\
& Temel yaşantı & 1 \\
& Bakış açısı & 2 \\
& Deneyim & 1 \\
& Sorumluluk & 1 \\
& Ergenlik & 2 \\
& Bireysel hız & 1 \\
\hline \multirow{2}{*}{ Cinsiyete Göre Uzaktan Eğitim } & Kiz öğrenci & 2 \\
& Sosyo-kültürel yapı & 1 \\
& Ergenlik & 2 \\
\hline
\end{tabular}

Araştırmanın üçüncü sorusuna ilişkin öğretmenlerin görüşleri incelendiğinde, bu araştırmaya katılan öğretmenlerin \%70'i uzaktan eğitime katılan öğrencilerin yaşının önemli olduğunu, geriye kalan öğretmenlerin \%20'si ise yaşın önemli bir faktör olmadığını belirtmiştir. Bu soruya cevap veren öğretmenlerin görüşleri incelendiğinde öğrencilerin bakış açılarının, deneyimlerinin ve sorumluluk bilincinde olmalarının yaş değişkeni ile ilişkilendirildiği görülmektedir. Yine aynı soru içerisinde yer alan cinsiyet değişkeninin önemi ile ilgili, araştırmaya katılan öğretmenler \% 90 oranında cinsiyetin uzaktan eğitim sürecini etkilemeyeceğini, geriye kalan öğretmenlerin \% 10 "unun ise tam tersini düşündükleri görülmüştür. Öğretmenler tarafından cinsiyet ile ilişkili olabilecek kodlar; kız öğrencilerin, ergenlik döneminin ve yine sosyo-kültürel yapı ile ilgili düşüncelerin uzaktan eğitim sürecinde etkili olabileceği şekilde belirtilmiştir. Üçüncü soruya yönelik bazı öğretmenlerin görüşleri aşağıda verilmiştir:

"Fen bilimleri dersinde çoğunlukla deneyimlediğimiz ya da tanık olduğumuz olaylara bilimsel bakış açısıyla yaklaşırız. Belli başlı temel yaşantılar olmadan bilgiyi ve bilimsel yöntemi inşa edebileceğimiz bir temel yok demektir. Küçük yaş gruplarında bu temeli uzaktan eğitimle oluşturmak apayrı bir yaklaşım gerektirir. Kontrollü ortam sağlamak ise oldukça zordur. Somut düşüncenin sinırlılı̆̆ında sanal kaynaklar görsel ya da işitsel ezberden öteye gidemeyebilir. Kısaca yaş oldukça kritik bir konu bence. Bu sorunun cevabı tamamen ailenin sosyo-kültürel yapısına bağhı olarak değişir. Ailedeki imkanların dă̆ıtılması, öncelikli kişinin belirlenmesi ve toplumsal cinsiyetlere bakış açısı eğitimin her türünde önemlidir zaten". (Ö5)

"Yaşı küçük öğrenci grupları daha fazla sorumluluk sahibi olduğu için katılım daha fazla oluyor. Yaş arttıkça ergenlik dönemi ile birlikte ilgi dağıldı̆̆ı için uzaktan eğitime katılım konusunda problemler yaşanıyor. Kız öğrencilerin ders çalışma istekleri her zaman erkeklerden daha fazla olduğu için uzaktan eğitime kız öğrenciler erkeklerden daha fazla katılım sağlıyor." (Ö6)

Araştırmanın dördüncü sorusu "Fen Bilimleri Derslerinde uzaktan eğitimde hangi yöntemtekniklerin kullanılması akademik başarıyı ve motivasyonu destekler?" şeklinde olup elde edilen tema ve kodlar aşağıda sunulmuştur (Tablo 4). 
Tablo 4. Dördüncü Soruya ait Tema ve Kodlar

\begin{tabular}{lll}
\hline Tema & Kod & Frekans \\
\hline & Plan & 1 \\
& Deney & 2 \\
Etkinlik & 2 \\
Göntem ve teknik & Soru cevap & 1 \\
& Problem çözme & 4 \\
& Tartışma & 1 \\
& Örnek olay & 2 \\
Sunuş & 1 \\
& Web 2.0 Araçları & 2 \\
& Beyin firtınası & 2 \\
Çoklu zeka & 2 \\
Buluş & 1 \\
Sanal laboratuvar & 1 \\
Gösterip yaptırma & 1 \\
\hline
\end{tabular}

Tablo 4 incelendiğinde, öğretmenlerin uzaktan eğitimde buluş, sunuş ve çoklu zekâ gibi yöntemlerin yanı sıra; soru cevap, beyin fırtınası ve örnek olay gibi de teknikler kullandıkları görülmektedir. Araştırmanın dördüncü sorusuna ilişkin bazı öğretmenlerin görüşleri aşağıda verilmiştir:

“Dijital dünyada etkili bir eğitim gerçekleştirmek için etkin katılım çok önemli bir faktördür. Buluşa yönelik yöntemler kullanılmall. Buluş yöntemini destekleyecek tartışma, beyin firtınası, soru-cevap ve gösteri gibi teknikler uzaktan eğitimde akademik başarııı ve motivasyonunu olumlu yönde etkileyecektir".(Ö7)

"Uzaktan eğitimde fen bilimleri dersine başlamadan önce çok dikkatli bir şekilde dijital ders planı hazırlanmalıdır. Bu planlama yapılırken fen bilimlerinin deney tabanlı bir ders olması ve bu deneylerin belirli güvenlik önlemleri altında yapılması gerektiği bilinmeli, 5-6-7-8. Sinıf müfredatında bulunan ve ögrencilerin evlerinde yapabilecekleri deneyler/etkinlikler buna göre planlanmalıdır. Ancak uzaktan eğitimde bilgi verilmeden önce öğretmenin dikkat etmesi gerekli olan bir durum vardır. "Fen Hayattır" yani fen bilimleri dersindeki her konunun gerçek hayatta bir örneği vardır. O yüzden öğretmenin bilgiyi vermeden önce bu örnekleri bulup öğrenciye bilgiyi bu örnekler üzerinden aktarması gerekir". (Ö1)

Araştırmanın beşinci sorusu “Fen Bilimleri Derslerinde uzaktan eğitimde çevirimiçi uygulamalar etkili midir? Neden?" şeklinde olup elde edilen tema ve kodlar aşağıda sunulmuştur (Tablo 5).

Tablo 5. Beşinci Soruya ait Tema ve Kodlar

\begin{tabular}{lll}
\hline Tema & Kod & Frekans \\
\hline & Etkileşim & 2 \\
& Dönüt & 3 \\
& Görsellik & 1 \\
\hline
\end{tabular}




\begin{tabular}{lll}
\hline & Aktif katılım & 1 \\
Ķevrimiçi uygulamalar & Kalıık & 1 \\
& Motivasyon & 4 \\
& Somutlaştırma & 2 \\
& Dikkat çekme & 2 \\
Merak & 1 \\
& İş birliği & 1 \\
& Tutum & 1 \\
\hline
\end{tabular}

Araştırmanın beşinci sorusuna ilişkin öğretmenlerin görüşleri incelendiğinde, bu araştırmaya katılan öğretmenlerin \% 60'1 uzaktan eğitimde çevrimiçi uygulamaların etkili olduğunu, geriye kalan öğretmenlerin \% 20'si ise uzaktan eğitimde çevrimiçi uygulamaların önemli bir faktör olmadığını belirtmiştir. Bu soruya cevap veren öğretmenlerin görüşleri incelendiğinde çevirim içi uygulamaların; öğretmene, öğrenciyle direk etkileşimde bulunma imkânı sağladığı için önemli olduğu vurgulanmıştır. Bu etkileşimle öğretmenler; derse karşı motivasyonu sağlama, öğrencilerin derse karşı dikkatini çekmeyi başarma ve öğrenciden anında dönüt almayı yapabildikleri için uzaktan eğitimde çevrimiçi uygulamaların etkili olduğu vurgulanmıştır. Beşinci soruya ilişkin öğretmenlerin görüşleri aşağıda verilmiştir:

"Uzaktan eğitimde çevirim içi uygulamaların kullanımı gereklidir. Sadece öğretmenin konuştuğu düz anlatım yerine çevrimiçi uygulamalar ile zenginleştirilmiş bir ders öğrenciye görsel anlamda daha çok akılda kalıcı olur. Ayrıca çevrimiçi uygulamalarla öğrenci derse daha aktif katılır ve motivasyonu yükseltilir. Böylece kalıcı öğreneler să̆lanabilir". (Ö2)

"Fen Bilimleri Derslerinde uzaktan eğitimde çevirim içi uygulamaların etkili olduğunu düşünüyorum. Öğrenciler böylece derslerde daha çok dikkat toplayabilir". (Ö4)

Araştırmanın altıncı sorusu "Fen Bilimleri Derslerinde uzaktan eğitimin verimliliği hakkında ne düşünüyorsunuz?" şeklinde olup elde edilen tema ve kodlar aşağıda sunulmuştur (Tablo 6).

Tablo 6. Altınc Soruya ait Tema ve Kodlar

\begin{tabular}{lll}
\hline Tema & Kod & Frekans \\
\hline & Hiçyoktan iyidir & 1 \\
& Yetersiz & 4 \\
Uzaktan eğitim verimliliği & Duruma göre değişir & 2 \\
& Yarı yarıya & 1 \\
& Teknolojik imkân & 1 \\
& Sikıcı & 1 \\
\hline
\end{tabular}

Tablo 6 incelendiğinde, bu araştırmaya katılan öğretmenlerin genel olarak uzaktan eğitime çok ılımlı bakmadığı, ancak salgın koşulları nedeniyle başvurulan bir durum olduğu belirtilmiştir. Öğretmen görüşlerinde yapılan analizlerde en çok öne çıkan kodun, uzaktan eğitimin yetersiz olduğudur. Uzaktan eğitime başvurulan duruma göre değişkenlik gösterebileceğini belirten öğretmen görüşleri olduğu gibi, bu verimliliğin teknolojik imkânlara bağlı olduğunu vurgulayanlar da olmuştur. Araştırmanın altıncı sorusuna ilişkin öğretmenlerin görüşleri aşağıda verilmiştir:

"Öğretmene, öğrenciye ve imkânlara bağhl olarak verimliliğin değişken olduğunu düşünüyorum". (Ö5) (Ö9)

"Yeterli olmadığını düşünüyorum. Öğrencilerin hepsine aynı anda ulaşamadığımız için".

"Pandemi dolayısı ile okullar kapandı̆̆ı için mecbur olduğumuz uzaktan eğitimin 
verimliliği, yüz yüze eğitimden her hâlükârda daha azdır. Ancak tek cümle ile özetlenebilir: Hiç yoktan iyidir". (Ö1)

Araştırmanın yedinci sorusu “Fen Bilimleri Derslerinde uzaktan eğitimin kullanılması gelecekte çocukları nasıl etkiler?" şeklinde olup elde edilen tema ve kodlar aşağıda sunulmuştur (Tablo 7).

Tablo 7. Yedinci Soruya ait Tema ve Kodlar

\begin{tabular}{lll}
\hline Tema & Kod & Frekans \\
\hline \multirow{3}{*}{ Uzaktan eğitimin etkisi } & Unutmak & 2 \\
& Ezber bilgi & 1 \\
& Bilgi kırıntısına & 1 \\
& Eksik Öğrenme & 2 \\
& Bağımlılık & 1 \\
& İlginin azalması & 1 \\
& Asosyallik & 1 \\
& İş Disiplinin olmaması & 1 \\
\hline \multirow{3}{*}{ Olumlu } & Kişisel gelişim & 1 \\
& Geleceğe ön hazırlık & 1 \\
\hline
\end{tabular}

Tablo 7 incelendiğinde, fen bilimleri derslerinin uzaktan eğitim ile işlenmesi gelecekte öğrencilerin şuan ki öğrendikleri bilgileri unutmasına neden olacağ 1 yönündedir. Uzaktan eğitimle ile derslerin eksik öğrenmeye sebep olacağı, ezber bilgiye neden olacağı ve derslere olan ilginin azalması yönünde olacağı belirtilmiştir. Araştırmanın yedinci sorusuna ilişkin öğretmenlerin görüşleri aşağıda verilmiştir:

“Birincil yaşantıları olmayan öğrencilerin yüz yüze eğitimde öğrenebilecekleri bilgileri uzaktan eğitimde alamayacakları için gelecekte öğrenciler fen bilimleri ile ilgili konuları ya unutacaklar ya da "kulaktan dolma" tanımına uygun şekilde ezber bilgiye/bilgi kırıntısına sahip olacaklardır". (Ö1)

"Bazı öğrencilerde dijital eğitimin kazanımları ileride onlara fayda sağlayacakken, bazı öğrencilerde de bă̆ımlılık sonucu oluşabilecek eksiklikler gözlenebilir".(Ö3)

Araştırmanın sekizinci sorusu "Fen Bilimleri Derslerinde gelecekte uzaktan eğitim uygulamaları artar mı? Neden?" şeklinde olup elde edilen tema ve kodlar aşağıda sunulmuştur (Tablo 8).

Tablo 8. Sekizinci Soruya ait Tema ve Kodlar

\begin{tabular}{lll}
\hline Tema & Kod & Frekans \\
\hline & Risk grubundaki öğrenciler & 1 \\
& Virüsle yaşamayı öğrenme & 1 \\
& Farklı yöntem ve teknik & 2 \\
Gelecekte uzaktan eğitimin daha & Motivasyon & 2 \\
fazla yaygınlaştırmasının & Dikkat çekme & 1 \\
sebepleri & Alternatif eğitim & 1 \\
& Kolaylik & 1 \\
& Bireysel gelişim imkânı & 2 \\
& Mekândan bağımsız & 2 \\
& Teknolojinin gelişmesi & 1 \\
& Enerji tasarrufu & 1 \\
& Zaman & 1 \\
\hline
\end{tabular}


$\mathrm{Bu}$ araştırmaya katılan öğretmenler, genel olarak uzaktan eğitimin gelecekte artacağını düşünmektedir. Tablo 8 incelendiğinde, öğretmen görüşlerinde yapılan analizlerde en çok öne çıkan fikirler; uzaktan eğitimin mekândan bağımsız olması, bireysel gelişim hızına uygun olması, farklı bir yöntem teknik olduğu ve motivasyonu bu neden ile olumlu etkileyeceği yönündedir. Araştırmanın sekizinci sorusuna ilişkin öğretmenlerin görüşleri aşağıda verilmiştir:

“Bence artması gerekir. Çünkü bütün derslerde olduğu gibi fen bilimleri derslerinde de öğrencileri daha da motive edecek yeni, farklı ve dikkat çeken uygulamalar oluşturulması adına uzaktan eğitim önemli bir seçenektir". (Ö3)

"Artar çünkü günümüz şartlar ve ilerleyen teknoloji bunu gerektirmektedir. Her ne kadar yüz yüze eğitim çok daha verimli olsa da, uzaktan eğitim hem zaman, hem mekan, hem de enerjiden tasarruf edilebilmeyi sağlaması adına, gelecekte tamamen uzaktan eğitime geçileceğini düşünüyorum". (Ö6)

"Muhtemelen gelecekte uzaktan eğitim uygulamaları artacaktır. Özel kurslarda, kişisel alınan eğitimlerde, farklı şehirlere yolculuk yapmadan istenilen yerden uzaktan eğitimle, istenilen eğitime ulaşma imkanı, insanlara büyük avantaj ve kolaylık să̆lıyor". (Ö5)

Araştırmanın dokuzuncu sorusu "Fen Bilimleri Derslerinde uzaktan eğitim ile işlenmesinde karşılaştığınız sorunlar nelerdir?" şeklinde olup elde edilen tema ve kodlar aşağıda sunulmuştur (Tablo 9).

Tablo 9. Dokuzuncu Soruya ait Tema ve Kodlar

\begin{tabular}{lll}
\hline Tema & Kod & Frekans \\
\hline & Ciddiyet & 4 \\
& Öğrenme ortamı & 1 \\
& Öğrenme kuralları & 1 \\
Öğrenci kaynaklı & Eksik öğrenme & 1 \\
& Yetersiz katılım & 1 \\
& Ailenin ihmali & 1 \\
& Fiziksel ortam & 1 \\
& Yetersiz güdülenme & 1 \\
\hline Öğretmen kaynaklı & Yöntem eksikliği & 1 \\
& Somutlaştıramama & 1 \\
\hline \multirow{3}{*}{ Teknik problemler } & İnternet & 5 \\
& Öğrenme araci eksikliği & 3 \\
\hline \multirow{3}{*}{ Sistemsel problemler } & Firsat eşitsizliği & 2 \\
& Online laboratuvar olmaması & 2 \\
& Kazanimların soyut olması & 1 \\
& Kalıcılı̆̆ın sağlanamama & 1 \\
& Etkileşim & 2 \\
\hline
\end{tabular}

Tablo 9 incelendiğinde, bu araştırmaya katılan öğretmenlerin uzaktan eğitimde karşılaştı̆̆1 sorunları öğrenci, öğretmen, teknik ve sistem başlıkları altında değerlendirdikleri görülmektedir. Öğrencilerle ilgili karşılaşılan sorunlar; öğrencilerin derslerde yeterince ciddiyete sahip olmamaları, öğrencilerin derslere yeterli katılım sağlamamaları, eksik öğrenmelerin giderilememesi gibi faktörle olarak sıralanmaktadır. Öğretmenlerle ilgili karşılaşılan sorunlar; uzaktan eğitimde yöntem eksikliği ve öğrenme sürecini öğrenci için somutlaştırmamaları olarak belirtilmektedir. Teknik problemlerde; internet bağlantılarında yaşanan sorunlar ve öğrenme aracı eksikliği gibi nedenlerle yaşanan fırsat eşitsizliği durumları ön plana çıkmaktadır. Uzaktan eğitim sürecinde yaşanan sistemsel problemler ise; online laboratuvarların olmaması, öğrenciyle etkileşimin tam 
sağlanamaması gibi durumlar bu araştırmaya katılan öğretmenler tarafından vurgulanmaktadır. Araştırmanın dokuzuncu sorusuna ilişkin öğretmenlerin görüşleri aşağıda verilmiştir:

“En büyük zorluklardan bir tanesi öğrencinin derse karşı gerekli ciddiyeti göstermemesidir. Bazı öğrenciler yatarak derslere katılmaktadır. Fakat psikolojik olarak insan bir şeyi öğrenmeden önce gerekli öğrenme ortamın tüm ciddiyetiyle kurmalıdır. Yani öğrenmenin de "Kuralları" vardır. Bu kuralların herhangi birine uyulmaması durumunda, ögrrenmenin tam manasıyla gerçekleştiği söylenemez". (Ö1)

"Online laboratuvar ortamlarınin olmaması kazanımlarm soyut kalmasina neden olmaktadır. Maalesef öğrencilerin zihinlerinde somutlaşamayan bilgi de kalıcı olmamaktadır". (Ö3)

“Her öğrencinin derse katılamaması en büyük sorun. Çünkü sınıfın bir bölümü ilerlerken diğer bölümü geride kahyor. Cihaz, internet gibi gerekliliklerin sağlanamaması öğrenciler arasında firsat eşitsizliliği olarak karşımıza çıkıyor". (Ö5)

Araştırmanın onuncu sorusu "Fen Bilimleri Derslerinin uzaktan eğitim ile işlenmesinde öğretmen ve öğrenciler için önerileriniz nelerdir?" ş̧eklinde olup elde edilen tema ve kodlar aşağıda sunulmuştur (Tablo 10).

Tablo 10. Onuncu Soruya ait Tema ve Kodlar

\begin{tabular}{lll}
\hline Tema & Kod & Frekans \\
\hline & Belgesel & 1 \\
& Dijital ders plan & 4 \\
& Ders Kaydı & 1 \\
& Ön hazırlı & 1 \\
Öğretmen için öneriler & Teknolojinin verimli kullanımı & 3 \\
& Kendini geliştirmeli & 2 \\
& Dönüt kullanımı & 3 \\
& Değerlendirme & 1 \\
& Hizmet içi eğitim & 1 \\
\hline \multirow{3}{*}{ Öğrenci için öneriler } & Kitap okumak & 1 \\
& Belgesel & 1 \\
& Etkili dinleme & 1 \\
& Kamerayla derse katılma & 2 \\
& Uygun fiziksel ortam & 2 \\
& Kendini geliştirmeli & 1 \\
\hline
\end{tabular}

Tablo 10 incelendiğinde, bu araştırmaya katılan öğretmenlerin uzaktan eğitim ile ilgili önerilerini, öğretmenlere ve öğrencilere olmak üzere ikiye ayırdıkları görülmektedir. Öğretmenler için öneriler; uzaktan eğitime özgü dijital ders planı hazırlama, teknolojiyi verimli kullanma ve derslerde öğrencilere olabildiğince dönüt verme şeklinde belirtilmiştir. Öğrenciler için öneriler ise; uygun fiziksel ortamı oluşturma, kamera ile derse katılma ve derse katılımda istekli olma şeklindedir. Araştırmanın onuncu sorusuna ilişkin öğretmenlerin görüşleri aşağıda verilmiştir:

"Fen bilimleri dersleri uzaktan işlenirken öğretmen kesinlikle önceden plan yapmalı ve bu plan doğrultusunda hareket etmelidir. Dersler online işlenirken kayıt altına alınmalı ve daha sonra öğrencilerin tekrar ulaşabileceği platformlarda hazırda bulundurulmalıdır. Öğrencilerin derslere hazırlıkl gelmeleri ve ilerleyen zamanlarda öğrencilerin uzaktan eğitime katılabilmesi için donanıml uzaktan eğitim laboratuvarları kurulmalıdır. Böylece belirli saatlerde öğrencilere 
bu ortamlardan faydalanabilir". (Ö2)

"Fen bilimleri dersleri uzaktan eğitim ile devam ederken, öğrenciler derse katılmadan önce uygun fiziksel ortamı oluşturmalıdır. Sonuçta bu süreç bir tatil değil, derslerin devam etmesi gerekmektedir. Yine öğrenciler olabildiğince derslere katılmalı ve gerekli ciddiyeti göstermelidir. Ders esnasında kamera ve ses sistemi açık olmal, böylece gerektiğinde hem öğretmen ile hem de arkadaşları ile etkileşim içinde olunabilir. Bu süreçte sınavları yapılamaması büyük sorun oluşturmaktadır. Öğrenciler derslerine devam ederken, kendilerini geliştirmek ve ilerde mutlu bireyler olmak için sorumlulukların yerine getirmelidir. Ö̆̆retmenlerde bu süreçte olabildiğince, öğrencilerde farkındalık oluşturma adına çaba harcamalıdır". (Ö7)

“Öğretmenler derslerini işlerken hep ayn ekran ve uygulamalar yerine, farklısiteler ve programlarla dersi çeşitlendirmelidir. Öğretmenler dersin son 5-10 dakikasında, öğrencilerden dersle ilgili geri bildirim almalıdır. Öğrenciler canlı derse katıldıkları ortamı, sessiz ve bağımsız bir şekilde düzenlemelidir. Beşinci ve altıncı sını ö̆̆grencilerinin verdiğ ï̈rneklerin birbiriyle ayn minvalde olması durumunda zaman kaybını engellemek için örnek vermeler kısıtlanabilir. Mouse yerine çizim tabletleri kullanmaları, şekiller üzerinde yapılan işaretlemelerde ve ekstra çizimlerde detayları vurgulamak için daha etkili olacaktır". (Ö10)

\section{TARTIŞMA, SONUÇ ve ÖNERILLER}

Hatay'da görev yapan fen bilimleri öğretmenlerinin uzaktan eğitime yönelik görüşlerinin incelenmesinin amaçlandığı bu araştırmada, öğretmenlerin çoğunluğu uzaktan eğitimi yeterli bulmadığını ifade etmektedir. Öğretmenlerin genel görüşü salgın koşullarından dolayı uzaktan eğitimin kaçınılmaz bir yöntem olduğu yönündedir. Bu araştırmaya katılan öğretmenler, bundan sonraki süreçte de uzaktan eğitimin, hayatın bir parçası olacağını düşünmektedir. Görgülü-Arı ve Hayır-Kanat (2020), Covid-19 sürecinde öğretmen adaylarının görüşlerini ortaya çıkarmayı hedeflediği araştırmada, uzaktan eğitimin yüz yüze eğitimin yerini tutmadığı yönünde bulgulara ulaşmışlardır. Buna karşın Moçoşoğlu ve Kaya (2020), Korona virüs hastalığ (Covıd-19) nedeniyle gerçekleştirilen uzaktan eğitime sürecinde öğretmen tutumlarının incelemiş ve elde ettikleri sonuçlarda öğretmenlerin uzaktan eğitimi faydalı olarak nitelendirdiğini ortaya çıkarmışlardır.

Araştırmanın birinci alt probleminde fen bilimleri öğretmenlerinin uzaktan eğitim sürecinde kullandığı araçlara yönelik öğretmenlerin çoğunluğunun Zoom, Eba uygulamalarını ve Web 2.0 Tasarım araçlarını kullandıkları görülmektedir. Bu soru için ulaşılan veriler Schulmeister ve Crosier (2020) tarafından yapılan araştırma ile benzer bulguları içermektedir. Schulmeister ve Crosier (2020) yaptıkları araştırmada bazı Avrupa ülkelerinde uzaktan eğitimin okullar tarafından dağıtılan kitaplar yardımıyla gerçekleştirilirken büyük çoğunluğunda uzaktan eğitimin çeşitli çevrimiçi öğrenme platformları, ulusal televizyon programları ve sosyal platformlar yardımıyla gerçekleştirildiğini ifade etmişlerdir. Ayrıca Bakioğlu ve Çevik (2020) gerçekleştirdiği araştırmada öğretmenlerin uzaktan eğitim sürecinde en çok başvurduğu dijital materyallerin; $Z$ kitap benzeri çevrimiçi uygulamalar, Eğitim Bilişim Ağı (EBA) ve çeşitli videolar olduğunu belirtmişlerdir.

Araştırmanın ikinci alt probleminde fen bilimleri öğretmenlerinin büyük çoğunluğu (N=8) uzaktan eğitim sürecinde teknolojik (Bilgisayar, telefon, tablet vb.) araçlarla uzun süre etkileşime giren öğrencilerde bağımlılı̆̆ın gelişeceği yönünde fikir beyan etmiştir. Yılmazsoy ve Kahraman (2020)" de öğrencilere yönelik yaptıkları araştırmada, uzaktan eğitim sürecinde bilgisayar başında geçirilen sürenin artmasının bağımlılığı arttıracağı yönündedir. Yine aynı araştırmada teknoloji bağımlılı̆̆ının gerçekleşmesine ve artmasına neden olarak; internete ayrılan sürenin artması ve 
sosyal ağlara daha çok katılma isteği gösterilmiştir. Bu durumun kontrol altına alınmaması halinde öğrencilerde teknolojik bağımlılığına neden olabileceği yönünde görüş belirtmiştir. Benzer şekilde Yılmazsoy ve Kahraman (2020) tarafından gerçekleştirilen araştırmada da öğretmenler öğrencilerin sürekli teknolojik aletlere maruz bırakılmasının öğrencilerde teknolojik bağımlılık gelişmesine nedeni olabileceği yönünde görüş oraya koymuştur.

Araştırmanın üçüncü alt probleminde, öğretmenlerin uzaktan eğitimin öğrencilerin cinsiyet ve yaş değişkenine göre farklılık gösterip göstermediğine dair görüşleri incelenmiştir. Araştırmaya katılan öğretmenlerin \% 70'i uzaktan eğitime katılan öğrencilerin yaşının önemli olduğu yönündeyken, öğretmenlerin geriye kalan \% 20"sinin ise yaşın önemli bir faktör olmadığını belirttikleri görülmüştür.

Uzaktan eğitim sürecinde öğretmenlerin kullandığı yöntem ve tekniklere yönelik bulgular incelendiğinde; buluş, sunuş ve çoklu zekâ gibi yöntemlerin yanı sıra soru cevap, beyin fırtınası ve örnek olay gibi de teknikler kullandıkları tespit edilmiştir. Yine Bakioğlu ve Çevik (2020) Covid-19 salgın sürecinde fen bilimleri öğretmenlerinin uzaktan eğitime ilişkin görüşlerini incelediği araştırmalarında, en çok kullandıkları öğretim yöntemlerinin; soru-cevap, problem çözme ve düz anlatım yöntemleri olduğu yönündeki bulgular bu araştırma sonucuyla örtüşmektedir.

Uzaktan eğitim sürecinde çevrimiçi uygulamaların etkililiğine yönelik bulgular incelendiğinde, öğretmenlerin büyük kısmının (\% 80'i) çevrimiçi uygulamaların daha etkili olduğunu düşündükleri belirlenmiştir. Öğretmenlerin çoğunluğu uzaktan eğitimin, gelecekte eğitim-öğretim hayatının vazgeçilmez bir parçası olacağı yönündedir. Yıldız (2011) bilgisayar öğretmeni adaylarıyla gerçekleştirdiği araştırmada, bilgisayar öğretmen adaylarının web tabanlı uzaktan eğitime yönelik kullanımlarının gelecekte artacağına inandıklarını belirtmiştir. Elde edilen veriler, bu araştırma ile de ulaşılan bulgularla örtüşmektedir.

Gelecekte uzaktan eğitimin öğrenciler üzerindeki etkisine yönelik fen bilimleri öğretmenlerinin görüşleri genel olarak olumsuz yöndedir. Öğretmenler uzaktan eğitimin, öğrencilerde özellikle ezbere yönelik bilgiler oluşturacağını belirtmiştir. Tuncer ve Bahadır (2017) yaptıkları araştırmada, uzaktan eğitimin öğrencilerdeolumsuz tutumlara ve ezber öğrenmelere yol açtığına dair bulgulara ulaşmıştır. Ayrıca Birişçi'nin (2013) araştırmasında öğrencilerin uzaktan eğitime yönelik gerçekleştirdiği tutum araştırmasında, öğrencilerin yüz yüze eğitimde sahip olduğu motivasyon ve ciddiyete, uzaktan eğitimde sahip olmadığı yönündeki çıkarımlar da bu araştırmada yer alan fen bilimleri öğretmenlerinin uzaktan eğitimin kısmen yeterli olduğu görüşünü destekler niteliktedir.

Uzaktan eğitime yönelik öğretmenlerin yaşadıkları probleme yönelik bulgular incelendiğinde; öğrencilerin derslerde yeterince ciddiyete sahip olmamaları, öğrencilerin derslere yeterli katılım göstermemeleri, eksik öğrenmelerin giderilememesi gibi sorunlar sıralanmaktadır. Uçar ise, 2016 yılında yaptığı araştırmada uzaktan eğitim sürecinde motivasyon stratejilerini uygulamış ve bu stratejilerin uygulanmasının öğrencilerin derslere olan motivasyonunu arttırdığını tespit etmiştir. Uzaktan eğitim sürecinde motivasyona yönelik sorunların giderilmesinde motivasyon tasarım modeli stratejilerinin uzaktan eğitim sürecine entegre edilmesi önerilebilir (Uçar, 2016).

Ayrıca bu araştırma ile öğretmenlerin uzaktan eğitimde yöntem eksikliği ve öğrenme sürecini öğrenci için somutlaştırmamaları gibi sorunların olduğu görülmektedir. Öğretmenlerin çoğunluğunun internet bağlantılarında yaşanan sorunlar ve öğrenme aracı eksikliği gibi teknik aksaklıklarla ilgili sorunlar yaşadığı sonucuna da ulaşılmıştır. Akkuş ve Acar (2017) yaptıkları araştırmada, öğreticilerin yaşadıkları problemlerin çoğunlukla internete yönelik bağlantı kopukluğu, online eğitimlere yönelik içeriklerin yetersiz olması, ses iletimine yönelik aksaklıklar ve 
derslere olan etkin katılımın yetersizliğine yönelik sorunlar olduğu belirtilmiştir. Yine Kırmacı ve Acar (2018)'de yaptıkları araştırmada, genel olarak öğrencilerin internet erişimi konusunda problem yaşadıklarını ve öğrencilerin canlı derslerin saatine yönelik bilgi eksiklikleri bulunduğunu belirtmiştir.Fidan (2020)'nin araştırma sonuçlarına göre ise, öğretmenlerin uzaktan eğitimde erişim sıkıntısını en olumsuz yön olarak vurguladıkları görülmektedir. Literatürde ulaşılan veriler ile bu araştırma sonucunda elde edilen bulguların örtüştüğü görülmektedir.

Araştırmacılar, çalışma sonucunda elde edilen bulguların uzaktan eğitime geçişin zorunlu olduğu ve devam ettiği bu günlerde uzaktan eğitim anlayışına katkı sağlayacağını beklemektedirler.

$\mathrm{Bu}$ araştırma kapsamında araştırmaya katılan öğretmenlere, son soru olarak da uzaktan eğitim süreci ile ilgili öneriler sorulmuştur. Bu soruya cevap veren öğretmenlerin ortak görüşü; öğretmenlerin dijital ders planı oluşturmaları, öğrencilerin ise de uygun fiziksel ortamın sağlaması yönündedir. Öztürk (2005) tarafından yapılan araştırmada, teknolojik alt yapının kuvvetlendirilmesi, bilgi ve iletişim teknolojilerine erişimin yaygınlaştırılması ve bireylerin bu konuda bilinçlendirilmesi gerektiği belirtilmiştir. Bu yönüyle ortaya konulan öneriler ile bu araştırmada öğretmenler tarafından belirtilen fikirlerin örtüştüğü söylenebilir.

$\mathrm{Bu}$ araştırma ile elde edilen veriler ışığında, Türkiye'de öğrencilerin devam durumlarını kontrol edebilecek ve uygulamalı ödevler verebilecek bir platform kurulması önerilebilir. Yine öğretmenlerin kullanabileceği sanal laboratuvar uygulamaları ve çevrimiçi deney ortamlarına yönelik alanında uzman kurum/kuruluşlarla çeşitli işbirlikleri gerçekleştirilerek öğrencilerin bu sistemlere ücretsiz erişimi sağlanabilir.

Öğretim materyalleri ve ders içeriklerinin uzaktan eğitime uygun hale getirilmesi, öğrenciler arasında fırsat eşitliği sağlama ve teknolojik alt yapı sorunlarının giderilmesi, uzaktan eğitim ile ilgili pedagojik olarak öğretmenlere hizmet içi eğim desteği verilmesi bu araştırma ile ulaşılan diğer bir öneridir.

$\mathrm{Bu}$ araştırmanın katılımcılarını ortaokullarda görevli Fen Bilimleri öğretmen adayları oluşturmuştur. Diğer branşlardaki öğretmenlere yönelik de benzer araştırmaların gerçekleştirilmesi beklenmektedir. Ayrıca Covid-19 salgınının, eğitim sisteminin farklı paydaşlarına (öğrenci, öğretmen adayı, okul yöneticileri, öğretim programı, aile vb.) olan olumlu ya da olumsuz etkilerinin daha detaylı, boylamsal incelenmesinin literatür açısından olumlu olacağ 1 düşünülmektedir.

\section{KAYNAKLAR}

Ağır, F. (2007). Özel okullarda ve devlet okullarında çalışan ilköğretim öğretmenlerinin uzaktan eğitime karşı tutumlarının belirlenmesi. Yüksek Lisans Tezi, Fen Bilimleri Enstitüsü, Balıkesir Üniversitesi, Balıkesir.

Akkuş, İ. \& Acar, S. (2017). Eş zamanlı öğrenme ortamlarında karşılaşılan teknik sorunların öğretici ve öğrenen üzerindeki etkisini belirlemeye yönelik bir araştırma. İnönü Üniversitesi Ĕ̆itim Fakültesi Dergisi, 18(3), 363-376. doi:10.17679/inuefd.340479

Aktay, Y. (2002). Eğitimde küresel imkânlar-küreselleşen dünyada eğitimde fırsat eşitliği ve özgürleşim fırsatları üzerine. Kuram ve Uygulamada Ĕ̆itim Bilimleri Dergisi, 2(1), 7-22.

Alkan, C. (1997). Eğitim teknolojisi. Ankara: Anı Yayıncılık.

Bakioğlu, B. \& Çevik, M. (2020). COVID-19 pandemisi sürecinde fen bilimleri öğretmenlerinin

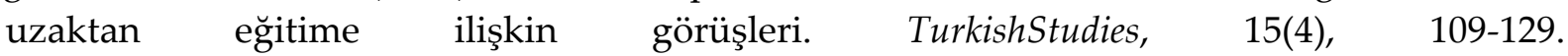
https://dx.doi.org/10.7827/TurkishStudies.43502.

Baş, Türker \& Akturan, Ulun (2008). Nitel araştırma yöntemleri. Ankara: Seçkin Yayıncılık 
Birişçi, S. (2013). Video konferans tabanlı uzaktan eğitime ilişkin öğrenci tutumları ve görüşleri. Journal of Instructional Technologies $\mathcal{E}$ TeacherEducation, 2(1). https://dergipark.org.tr/tr/pub/jitte/issue/25080/264691

Birkök, M. C. (2006). Uzaktan eğitimin sosyolojik kavramlarla analizi. Journal of Human Sciences, 1(1). Büyüköztürk, Ş., Çakmak, E. K., Akgün, Ö. E., Karadeniz, Ş., \& Demirel, F. (2008). Bilimsel araştırma yöntemleri. Pegem Akademi.

Creswell, J. W. (2014). Araştırma deseni: Nitel, nicel ve karma yöntem yaklaşımları (S. B. Demir, çev). Eğiten Kitap

Creswell, J. W. (2017). Eğitim araştırmaları. EDAM Eğitim Danışmanlığı ve Araştırmaları Merkezi.

Fidan, M. (2020). Covıd-19 belirsizliğinde eğitim: İlkokulda zorunlu uzaktan eğitime ilişkin öğretmen görüşleri. Uşak Üniversitesi Ĕ̆itim Araştırmaları Dergisi, 6 (2), 24-43

Glesne, C. (2012). Nitel araştırmaya giriş. (A. Ersoy ve P. Yalçınoğlu, Çev.). Ankara: Anı Yayıncılık.

Görgülü-Arı A.,\& Hayır-Kanat, M. (2020). COVID-19 (koronavirüs) üzerine öğretmen adaylarının görüşleri. Yüzüncü Yıl Üniversitesi Sosyal Bilimler Enstitüsü Dergisi, (Salgın Hastalıklar Özel Sayıs1), 459- 492. https://dergipark.org.tr/en/download/article-file/1210688

Hatch, J. A. (2002). Doingqualitativeresearch in educationsettings. SunyPress.

Höçük, M. (2011). Ankara üniversitesi uzaktan eğitim programına katılan öğrencilerin akademik başarıların etkileyen faktörler, Yüksek Lisans Tezi, Eğitim Bilimleri Enstitüsü,, Ankara Üniversitesi, Ankara.

Karadağ, E. ve Yücel, C. (2020). Yeni tip Koronavirüs pandemisi döneminde üniversitelerde uzaktan eğitim: Lisans öğrencileri kapsamında bir değerlendirme çalışması. Yükseköğretim Dergisi, 10(2), 181-192.

Koloğlu, T. F. (2016). Öğretim elemanlarnın uzaktan eğitime bakış açıları ve hazırbulunuşlukları: Ordu Üniversitesi Örneği YükssekLisansTezi, AfyonKocatepeÜniversitesi, Afyon.

Kırık, A. (2014). Uzaktan eğitimin tarihsel gelişimi ve Türkiye' deki durumu. Marmara İletişim Dergisi, (21), 73-94.

Kırmacı, Ö. \& Acar, S. (2018). Kampüs öğrencilerinin eşzamanlı uzaktan eğitimde karşılaştıkları sorunlar. Eğitimde Kuram ve Uygulama, 14(3), 276-291. doi:10.17244/eku.378138

Lloyd, S. A.,Byrne, M. M. \& McCoy, T. S. (2012). Faculty-perceivedbarriers of onlineeducation. Journal of Online Learning and Teaching, 5(1).

Marsh, B.,Mitchell, N., \& Adamczyk, P. (2010). Interactive video technology: Enhancingprofessionallearning in initialteachereducation. ComputersEEducation, 54(3), $742-$ 748.https://www.learntechlib.org/p/67149/

Malterud, K. (2001). Qualitativeresearch: Standards, challenges, andguidelines. TheLancet, 358(9280), 483-488.

Moçoşoğlu, B , Kaya, A . (2020). Koronavirüs hastalığ1 (COVID-19) sebebiyle uygulanan uzaktan eğitime yönelik öğretmen tutumlarının incelenmesi. Kahramanmaraş Sütçü İmam Üniversitesi Ĕ̈itim Dergisi, 2(1), $15-43$. Retrievedfromhttps://dergipark.org.tr/en/pub/ksued/issue/59531/800151

Moore, M. \& Kearsley, G. (2011). Distance Education: A System View of Online Learning. (Third Edition). Belmont, Calif: Wadsworth Pub. Co.

Morgan, D. L. (1996). Focus groups as qualitative research (C. 16). New York: Sage publications.

Özbay, Ö. (2015). Dünyada ve Türkiye'de uzaktan eğitimin güncel durumu. Uluslararası Ĕgitim Bilimleri Dergisi, (5), 376-394.

Öztürk, L. (2005). Türkiye'de dijital eşitsizlik: Tübitak-bilten anketleri üzerine bir değerlendirme. Erciyes Üniversitesi İktisadi ve İdari Bilimler Fakültesi Dergisi, 24, 111-131

Saban, A. \& Ersoy, A. (2017). Eğitimde nitel araştırma desenleri. Ankara: Anı Yayıcılık 
Schulmeister, A. \& Crosier, D. (2020). How is Covid-19 affectingschools in Europe? Researchreport. EuropeanCommission, EURYDICE. https://eacea.ec.europa.eu/nationalpolicies/eurydice/content/how-covid-19-affecting-schoolseurope

Shenton, A. K. (2004). Strategiesforensuringtrustworthiness in qualitativeresearchprojects. Educationforinformation, 22(2), 63-75.

Simonson, M.,Smaldino, S. E., Albright, M. \& Zvacek, S. (2012). Teachingandlearning at a distance: Foundations of distanceeducation. Boston: PearsonEducation, Inc.

Şen, Ü . (2016). Yabancı dil olarak Türkçe öğretiminde uzaktan eğitim programları. Ahi Evran Üniversitesi Kırşehir Eğitim Fakültesi Dergisi, 17

Retrievedfromhttps://dergipark.org.tr/tr/pub/kefad/issue/59426/853589

Tabata, L. N. \& Johnsrud, L. K. (2008). Theimpact of facultyattitudestowardtechnology, distanceeducation, andinnovation. Research in highereducation, 49(7), 625. https://link.springer.com/article/10.1007\%252Fs11162-008-9094-7

Tuncer, M. \& Tanaş, R. (2011). Akademisyenlerin uzaktan eğitim programlarına yönelik görüşlerinin değerlendirilmesi (Furat ve TunceliÜniversiteleriörneği).

Tuncer, M. \& Bahadır, F. (2017). Uzaktan eğitim programlarının bu programlarda öğrenim gören öğrenci görüşlerine göre değerlendirilmesi. Journal of EducationalReflections, 1(2), 29-38.

USDLA. (2004). United states distance learning association: Definition of distanc elearning. 16 Mart 2021 tarihindehttp://www.usdla.orgadresindenerişildi.

Uçar, H. (2016). Uzaktan eğitimde motivasyon stratejilerinin öğrenenlerin ilgileri, motivasyonları, eylem yeterlikleri ve başarıları üzerine etkisi. Yayımlanmamış Doktora Tezi, Sosyal Bilimler Enstitüsü, AnadoluÜniversitesi, Eskişehir.

Uşun, S. (2006). Uzaktan eğitim.(1.baskı) Ankara: Nobel Yayın Dağıtım.

Yıldırım, A. \& Şimşek, H. (2008). Sosyal bilimlerde nitel araştırma yöntemleri. Ankara: Seçkin Yayıncılık

Yıldız, E. (2011). Web-Tabanlı senkron derslerin öğretmen adaylarının uzaktan eğitime karşı tutumları ve senkron teknolojileri kabulleri üzerine etkisi. Yayınlanmamış Yüksek Lisans Tezi, Fen Bilimleri Enstitüsü, Balıkesir Üniversitesi, Balıkesir.

Yılmazsoy, B. \& Kahraman, M. (2020). Uzaktan eğitim öğrencilerinin internet bağımlılık düzeylerinin incelenmesi. Açık öğretim Uygulamaları ve Araştırmaları Dergisi , 3(4), 9-29.

Zırhlığlu, Ç. (2006). Türkiye genelinde ve bölgeler arasında bilgisayar kullanımı ve uzaktan eğitim ile ilgili istatistiksel analiz. Yüksek Lisans Tezi, Fen Bilimleri Enstitüsü, Marmara Üniversitesi, İstanbul. 